Open Access

Res. Agric. Livest. Fish.

Research Article

Vol. 5, No. 3, December 2018 : 313-320.

\title{
RESPONSE OF TRANSPLANTED AMAN RICE VARIETIES TO SPLIT APPLICATION OF POTASSIUM
}

\author{
Israt Jahan ${ }^{1^{\star}}$, Sarder Md. Altaf Hossain ${ }^{2}$, Md. Anwarul Islam ${ }^{2}$ and \\ Joynulalam Talukder ${ }^{3}$
}

${ }^{1}$ Additional Agriculture Officer, Department of Agricultural Extension, Purbadhala, Netrakona2412, Bangladesh; ${ }^{2}$ Department of Agronomy, Faculty of Agriculture, Bangladesh Agricultural University, Mymensingh-2202, Bangladesh; ${ }^{3}$ Horticulturist, Horticulture Centre, Department of Agricultural Extension, Shulakia, Kishoreganj-2300, Bangladesh.

*Corresponding author: Israt Jahan; E-mail : isratmym@gmail.com

ARTICLE INFO ABSTRACT

Received

27 October, 2018

Accepted

22 December, 2018

Online

27 December, 2018

Key words

Split application

Potassium

Fertilization

Grain yield

Rice
The research was conducted at the Agronomy Field Laboratory, Bangladesh Agricultural University, Mymensingh, to investigate the effect of time of split application of potassium on the yield of three transplanted $(T)$ aman rice varieties. Rice varieties were BRRI dhan39, BRRI dhan40 and BRRI dhan41. Potassium was applied at the rate of $80 \mathrm{~kg} \mathrm{~K} \mathrm{ha}^{-1}$. Experimental plot size was $5 \mathrm{~m}^{2}(2.5 \mathrm{~m} \times 2.0 \mathrm{~m})$. Four split application of potassium [ $\mathrm{K}_{1}=$ Control (No K application), $\mathrm{K}_{2}=40 \mathrm{~g} \mathrm{~K} \mathrm{plot}^{-1}$ at 15 DAT (days after transplanting), $\mathrm{K}_{3}=20 \mathrm{~g} \mathrm{~K} \mathrm{plot}^{-1}$ at15 DAT $+20 \mathrm{~g} \mathrm{~K} \mathrm{plot}^{-1}$ at 30DAT, $\mathrm{K}_{4}=10 \mathrm{~g}$ $\mathrm{K} \mathrm{plot}^{-1}$ at $15 \mathrm{DAT}+10 \mathrm{~g} \mathrm{~K} \mathrm{plot}^{-1}$ at 25DAT+ $10 \mathrm{~g} \mathrm{~K} \mathrm{plot}^{-1}$ at $30 \mathrm{DAT}+10 \mathrm{~g} \mathrm{~K} \mathrm{plot}^{-1}$ at 45 DAT] were considered as treatments. From the experiment it was found that split application of potassium had no significant effect on plant height, length of panicle, thousand grains weight. It was evident that two splits application of potassium i.e., 20 $\mathrm{g} \mathrm{K} \mathrm{plot}^{-1}$ at $15 \mathrm{DAT}+20 \mathrm{~g} \mathrm{~K} \mathrm{plot}^{-1}$ at 30 DAT with BRRI dhan41 gave maximum no. of tiller hill-1, effective tiller hill-1, grains panicle ${ }^{-1}$, grain yield and straw yield, biological yield and harvest index. But varieties differed among themselves in terms of yield contributing characters and yield, and BRRI dhan41 performed the best. Therefore, based on the findings of the present study, it may be concluded that for obtaining higher yield BRRI dhan 41 can be grown following application of potassium at the rate of $80 \mathrm{~kg} \mathrm{ha}^{-1}$ in two equal split at 15 and 30 days after transplanting.

To cite this article: Israt Jahan, Hossain SMA, Islam MA and Talukder J, 2018. Response of transplanted aman rice varieties to split application of potassium. Res. Agric. Livest. Fish. 5 (3): 313-320.

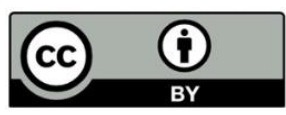

This is an open access article licensed under the terms of the Creative Commons Attribution 4.0 International License

www.agroaid-bd.org/ralf, E-mail: editor.ralf@gmail.com 


\section{INTRODUCTION}

Bangladesh is an important rice growing country of the world. The economy of Bangladesh is influenced markedly by rice. It covers 80 percent of the total cropped area (AIS, 2002). Rice is grown 9.94 million hectares of land with a total production of 2.35 ton ha-1 in Bangladesh (BBS, 2006). Among the three rice crops aus (summer rice), transplant aman (grown in monsoon) and boro (grown in winter), transplant aman rice covers about $56 \%$ of the total rice area. It covers the largest area of 5.6 million hectares with a production of 9.3 million tons of rice (BBS, 2004). The average yield of aman rice is $1.64 \mathrm{t} \mathrm{ha}^{-1}$ and HYV transplant aman rice is $3.83 \mathrm{t} \mathrm{ha}^{-1}$. The benefits of health of rice include its ability to provide instant energy, regulate and improve bowel movements, stabilize blood sugar levels and slow down the aging process. It's also plays a role in providing Vitamin B1 to the human body. On the other hand, potassium is a major inorganic constituent of plants and its deficiency affects several metabolic processes. A number of physiological disorders are directly related to insufficient uptake of potassium. Potassium helps control or reduces the severity of plant diseases and increase the plant resistance to drought and other stress. It also helps overcome "bronzing disease" caused by iron toxicity and prevents root damages caused by hydrogen sulphide or by organic substances. It performs many functions in plants such as promoting growth and increasing yield, aiding in the translocation of carbohydrates to maintain cell permeability, increases the efficiency of the leaf in manufacturing sugars, strengthening plants tissues and preventing lodging, increasing resistance to pests, promoting root growth in conjunction with adequate supply of phosphates, acts an activator of a number of amino acid-activating enzymes. Singh et al. (2006) conducted an experiment in a silt loam soil to evaluate the effect of potassium and potassium levels on growth yields and seed quality of hybrid rice. They reported that $80 \mathrm{~kg} \mathrm{~K} \mathrm{ha}^{-1}$.was found better to obtain higher production and good quality of hybrid rice.

\section{MATERIALS AND MOTHODS}

The experiment was carried out at the Agronomy Field Laboratory, Bangladesh Agricultural University, Mymensingh. The experimental site belongs to the agro-ecological zone 'Old Brahmaputra Floodplain', having Non-calcareous dark grey floodplain soil (UNDP and FAO, 1988). The land was medium high land with silt loam texture. The $\mathrm{pH}$ value of the soil was 6.5 , low in organic matter content. Its general fertility level was also low ( total $\mathrm{N}$ is $0.08 \%$, available $\mathrm{P}$ is $7.0 \mathrm{mg} \mathrm{kg}^{-1}$, exchangeable $\mathrm{K}$ is $0.07 \mathrm{me} / 100 \mathrm{gm}$ soil, available $S$ is $7.5 \mathrm{me} \mathrm{kg}^{-1}$ ). Potassium was applied in the field at the rate of $80 \mathrm{~kg} \mathrm{~K} \mathrm{ha}^{-1}$. Four levels of $\mathrm{K}$ $\left[\mathrm{K}_{1}=\right.$ Control (No K application), $\mathrm{K}_{2}=40 \mathrm{~g} \mathrm{~K} \mathrm{plot}^{-1}$ at 15 DAT (days after transplanting), $\mathrm{K}_{3}=20 \mathrm{~g} \mathrm{~K}$ plot $^{-1}$ at15 DAT+20 g K plot ${ }^{-1}$ at 30DAT, $\mathrm{K}_{4}=10 \mathrm{~g} \mathrm{~K} \mathrm{plot}^{-1}$ at $15 \mathrm{DAT}+10 \mathrm{~g} \mathrm{~K} \mathrm{plot}^{-1}$ at 25DAT+ $10 \mathrm{~g} \mathrm{~K} \mathrm{plot}^{-1}$ at $30 \mathrm{DAT}+$ $10 \mathrm{~g} \mathrm{~K} \mathrm{plot}^{-1}$ at $45 \mathrm{DAT}$ ] were considered as treatments.

The experiment was laid out in a split plot design with 3 replications having unit plot size of $5 \mathrm{~m}^{2}(2.5 \mathrm{~m}$ $\times 2.0 \mathrm{~m}$ ). Varieties were: BRRI dhan39, BRRI dhan40, BRRI dhan41 accommodated in the main plot and split application of potassium fertilizer (muriate of potash) was placed in the sub plot. Total number of plot was 36 . The layout was done on 20 July having $1 \mathrm{~m}$ and $75 \mathrm{~cm}$ spacing between replications and the unit plots, respectively. Land preparation involved ploughing, harrowing and leveling in the field to make it suitable for crop establishment by a four wheel tractor. Soil was flooded and irrigated once with sufficient water to bring the top soil saturation and create an overlying water layer. The water depth was $5 \mathrm{~cm}$ but 10 $\mathrm{cm}$ was maintained for about one week after transplanting. From 30 days before head formation and flowering to the start of maturity, soil was frequently covered with water to a depth of 8 or $10 \mathrm{~cm}$. A continual flow of water was maintained. The field was drained completely 30 to 45 days before harvest to ensure that the field would be dry enough for harvest. The source of $\mathrm{K}$ was commercially produced Muriate of Potash. Urea, Triple super phosphate, gypsum and zinc sulphate was applied at 120,100,60 and $10 \mathrm{~kg}$ $\mathrm{ha}^{-1}$ respectively during final land preparation. Thirty days old seedlings were transplanted from a nursery bed to the main field maintaining 3 seedlings hill ${ }^{-1}$ with a spacing of $20 \mathrm{~cm} \times 15 \mathrm{~cm}$. Necessary intercultural operations such as weeding, irrigation, pest management etc were performed accordingly and whenever 
needed to ensure the growth of a successful crop. Ten hills plot $^{-1}$ were randomly uprooted before harvesting in order to collect the following data : Total number of tillers hill ${ }^{-1}$, number of effective tillers hill ${ }^{-1}$, panicle length, number of grain panicle ${ }^{-1}$, number of unfilled spikelets panicle ${ }^{-1}$ grain yield, straw yield, biological yield, harvest index ( $\mathrm{HI}$ ). Data on grain and straw yield were recorded on a plot basis after drying in the sun maintaining $14 \%$ moisture, threshing, winnowing and finally converted to grain/straw weight per hectare.

All data were statistically analyzed with the help of MSTAT (Gomez and Gomez, 1984). Analysis of variance (ANOVA) was measured and significant differences between means were calculated by Ducan's multiple range test (DMRT).

\section{RESULT AND DISCUSSION}

\section{Effect of variety}

All yield contributing characters like plant height, total tillers hill ${ }^{-1}$, effective tillers hill $^{-1}$, panicle length, grain panicle ${ }^{-1}$, grain yield, straw yield, biological yield significantly responded to different levels of applied $\mathrm{K}$ (Table 1).Among the varieties, BRRI dhan41 showed superiority to BRRI dhan39 and BRRI dhan40 with respect to plant height, total tillers hill $^{-1}$, effective tillers hill ${ }^{-1}$, panicle length, grain panicle ${ }^{-1}$, grain yield, straw yield, biological yield (Table 1). On the other hand, BRRI dhan39 produced more no. of non- effective tillers hill $^{-1}$, unfilled spikelets panicle ${ }^{-1}$ and weight of 1000 grains than BRRI dhan41.Production of taller plant, higher number of tillers hill-1 favoured BRRI dhan41 to produce significantly higher straw yield, biological yield than BRRI dhan39. Though weight of 1000 grains is higher in BRRI dhan39 than BRRI dhan 41 but grain panicle ${ }^{-1}$ is more in BRRI dhan41 than BRRI dhan 39 which favoured to produce significantly higher grain yield. BRRI dhan40 gives moderate production in plant height, total tillers hill ${ }^{-1}$, effective tillers hill-1, panicle length, grain panicle ${ }^{-1}$, unfilled spikelets panicle ${ }^{-1}$, grain yield, straw yield, biological yield.

\section{Effect of split application of $\mathrm{K}$}

Effect of split application of $\mathrm{K}$ on effective tillers hill ${ }^{-1}$, non- effective tillers hill $^{-1}$, panicle length, grain panicle $^{-1}$, unfilled spikelets panicle ${ }^{-1}, 1000$ grains weight of grain yield, straw yield, biological yield is shown in Table 2. Potassium has a pronounced effect on three T.aman rice varieties i.e., BRRI dhan39, BRRI dhan40, BRRI dhan41 in producing maximum number of tillers hill ${ }^{-1}$, grain panicle ${ }^{-1}$, grain yield, straw yield, biological yield. Two split of potassium gives maximum number of tillers hill ${ }^{-1}$, effective tillers hill ${ }^{-1}$, grain panicle $^{-1}$, grain yield, straw yield, biological yield and minimum of number of non- effective tillers hill ${ }^{-1}$, unfilled spikelets panicle ${ }^{-1}$. On the other hand, at the basal dose, maximum number of unfilled spikelets panicle ${ }^{-1}$ was found. Four splits application of potassium i.e., $10 \mathrm{~g} \mathrm{~K} \mathrm{plot}^{-1}$ at $15 \mathrm{DAT}+10 \mathrm{~g} \mathrm{~K} \mathrm{plot}^{-1}$ at $25 \mathrm{DAT}+10 \mathrm{~g} \mathrm{~K} \mathrm{plot}^{-1}$ at $30 \mathrm{DAT}+10 \mathrm{~g} \mathrm{~K} \mathrm{plot}^{-1}$ at 45 DAT showed better performance than basal dose incase of total tillers hill-1, effective tillers hill ${ }^{-1}$, grain panicle ${ }^{-1}$, grain yield, straw yield and biological yield. More non- effective tillers hill ${ }^{-1}$ was found in four split application of potassium than basal. Maximum number of non- effective tillers hill ${ }^{-1}$ was found in one split application of potassium i.e. when $40 \mathrm{gm} \mathrm{K}$ was applied in the experimental plot. Fallah (1997) in his experiment with rice crop applied $250 \mathrm{~kg} \mathrm{~K} \mathrm{ha}^{-1}$ at 5 different dates. He reported that grain yield was increased by $\mathrm{K}$ application and was highest when $\mathrm{K}$ applied in two equal splits $(50 \%$ as basal application $+50 \%$ forty-five days after transplanting). Meena et al. (2003) conducted a field experiment at the Indian Agricultural Research Institute, Delhi to study the productivity and economics of Oryza sativa L. as influenced by $\mathrm{K}$ application. The experiment was laid out in split plot design with two levels of potassium, viz. 62.5 and $125 \mathrm{Kg} \mathrm{K} \mathrm{ha}^{-1}$. Significantly higher number of tiller, dry matter accumulation, grain and straw yields were recorded with the application of $62.5 \mathrm{Kg} \mathrm{K}^{-1}$ applied in two equal splits (half at transplanting and half at maximum tillering). 
Table1. Effect of variety on yield and yield contributing characters of $\mathrm{T}$. aman rice

\begin{tabular}{|c|c|c|c|c|c|c|c|c|c|c|c|c|}
\hline Variety & $\begin{array}{l}\text { Plant } \\
\text { height } \\
(\mathrm{cm})\end{array}$ & $\begin{array}{l}\text { Total tiller } \\
\text { hill }^{-1}\end{array}$ & $\begin{array}{l}\text { Effective } \\
\text { tillers } \text { hill }^{-1} \\
\text { (No.) }\end{array}$ & $\begin{array}{l}\text { Non-effective } \\
\text { tillers hill-1 } \\
\text { (No.) }\end{array}$ & $\begin{array}{l}\text { Length of } \\
\text { panicle } \\
(\mathrm{cm})\end{array}$ & $\begin{array}{l}\text { Grains } \\
\text { panicle }^{-1} \\
\text { (No.) }\end{array}$ & $\begin{array}{l}\text { Unfilled } \\
\text { spikeletspa } \\
\text { nicl-1 }^{-1} \text { (No.) }\end{array}$ & $\begin{array}{l}1000- \\
\text { grain } \\
\text { wt(g) }\end{array}$ & $\begin{array}{l}\text { Grain } \\
\text { yield } \\
\left(\mathrm{t} \mathrm{ha}^{-1}\right)\end{array}$ & $\begin{array}{l}\text { Straw } \\
\text { yield } \\
\left(\mathrm{t} \mathrm{ha}^{-1}\right)\end{array}$ & $\begin{array}{l}\text { Biological } \\
\text { yield } \\
\left(\mathrm{t} \mathrm{ha}^{-1}\right)\end{array}$ & $\begin{array}{l}\text { Harvest } \\
\text { index } \\
(\%)\end{array}$ \\
\hline $\begin{array}{l}\text { BRRI dhan } 39 \\
\text { (V1) }\end{array}$ & $83.93 c$ & $11.60 \mathrm{c}$ & $7.81 \mathrm{c}$ & $3.79 a$ & $23.87 b$ & $107.56 c$ & $25.79 a$ & 24.88 & $2.75 c$ & $3.84 \mathrm{c}$ & $6.59 c$ & 41.60b \\
\hline $\begin{array}{l}\text { BRRI dhan } 40 \\
\text { (V2) }\end{array}$ & $106.85 b$ & $12.39 \mathrm{~b}$ & $8.48 b$ & $3.91 a$ & $23.79 b$ & $144.57 b$ & $16.44 b$ & 24.93 & $4.23 b$ & $5.38 b$ & $9.61 b$ & $43.96 a$ \\
\hline $\begin{array}{l}\text { BRRI dhan } 41 \\
\text { (V3) }\end{array}$ & $126.87 a$ & $13.19 a$ & $11.12 \mathrm{a}$ & $2.07 b$ & $25.41 a$ & $165.77 a$ & $14.93 c$ & 24.71 & $4.56 a$ & $5.90 a$ & $10.46 a$ & $43.35 a$ \\
\hline$s \bar{X}$ & 4.90 & 0.12 & 0.12 & 0.11 & 0.17 & 0.84 & 0.40 & 0.21 & 0.03 & 0.05 & 0.06 & 0.35 \\
\hline $\begin{array}{l}\text { Level of } \\
\text { significance }\end{array}$ & 0.01 & 0.01 & 0.01 & 0.01 & 0.05 & 0.01 & 0.01 & NS & 0.01 & 0.01 & 0.01 & 0.05 \\
\hline
\end{tabular}

NS: Not significant; In a column, figures with same letter(s) or without letters do not differ significantly whereas figures with dissimilar letters differ significantly as per DMRT. 
Table 2. Effect of time of split application of $\mathrm{K}$ on yield and yield contributing characters of $\mathrm{T}$. aman rice

\begin{tabular}{|c|c|c|c|c|c|c|c|c|c|c|c|c|}
\hline $\begin{array}{l}\text { Time of split application } \\
\text { of } \mathrm{K}\end{array}$ & $\begin{array}{l}\text { Plant } \\
\text { height } \\
(\mathrm{cm})\end{array}$ & $\begin{array}{l}\text { Total } \\
\text { tiller } \\
\text { hill }^{-1}\end{array}$ & $\begin{array}{l}\text { Effectiv } \\
\text { e tillers } \\
\text { hill }^{-1} \\
\text { (No.) }\end{array}$ & $\begin{array}{l}\text { Non- } \\
\text { effective } \\
\text { tillers hill- } \\
{ }^{1} \text { (No.) }\end{array}$ & $\begin{array}{l}\text { Length } \\
\text { of } \\
\text { panicle } \\
(\mathrm{cm})\end{array}$ & $\begin{array}{l}\text { Grains } \\
\text { panicle }^{-1} \\
\text { (No.) }\end{array}$ & $\begin{array}{l}\text { Unfilled } \\
\text { spikelets } \\
\text { panicl }{ }^{-1} \\
\text { (No.) } \\
\end{array}$ & $\begin{array}{l}1000- \\
\text { grain } \\
\text { wt(g) }\end{array}$ & $\begin{array}{l}\text { Grain } \\
\text { yield }(t \\
\left.\text { ha }^{-1}\right)\end{array}$ & $\begin{array}{l}\text { Straw } \\
\text { yield } \\
\left(\mathrm{t} \mathrm{ha}^{-1}\right)\end{array}$ & $\begin{array}{l}\text { Biological } \\
\text { yield } \\
\left(\mathrm{t} \mathrm{ha}^{-1}\right)\end{array}$ & $\begin{array}{l}\text { Harvest } \\
\text { index } \\
(\%)\end{array}$ \\
\hline Control (K1) & 109.51 & $9.26 c$ & $6.42 d$ & $2.84 \mathrm{c}$ & 24.42 & $121.78 d$ & $21.78 \mathrm{a}$ & 24.62 & $2.98 d$ & $4.31 d$ & $7.29 d$ & $40.84 d$ \\
\hline $\begin{array}{l}40 \mathrm{~g} \mathrm{~K} \mathrm{plot}^{-1} \text { at } 15 \mathrm{DAT} \\
(\mathrm{K} 2)\end{array}$ & 108.58 & $13.04 b$ & $8.98 c$ & $4.06 a$ & 24.54 & $143.53 b$ & $19.08 b$ & 24.62 & $3.79 c$ & $5.08 c$ & $8.86 c$ & $42.44 \mathrm{c}$ \\
\hline $\begin{array}{l}20 \mathrm{~g} \mathrm{~K} \mathrm{plot}^{-1} \text { at } 15 \\
\text { DAT+20 g K plot }{ }^{-1} \text { at } \\
30 \mathrm{DAT}(\mathrm{K} 3)\end{array}$ & 109.03 & $13.87 a$ & $11.18 a$ & $2.69 c$ & 24.33 & $152.64 a$ & $15.50 \mathrm{c}$ & 24.96 & $4.49 a$ & $5.48 a$ & $9.96 a$ & $44.98 a$ \\
\hline $\begin{array}{l}10 \mathrm{~g} \mathrm{~K} \mathrm{plot}^{-1} \text { at } 15 \\
\mathrm{DAT}+10 \mathrm{~g} \mathrm{~K} \mathrm{plot}^{-1} \text { at } \\
25 \mathrm{DAT}+10 \mathrm{~g} \mathrm{~K} \mathrm{plot}^{-1} \\
\text { at } 30 \mathrm{DAT}+10 \mathrm{~g} \mathrm{~K} \text { plot }^{-} \\
1 \text { at } 45 \mathrm{DAT}(\mathrm{K} 4)\end{array}$ & 96.42 & $13.39 b$ & $9.95 b$ & $3.43 b$ & 24.16 & $139.24 c$ & $19.86 b$ & 25.15 & $4.14 b$ & $5.29 b$ & $9.44 b$ & $43.63 b$ \\
\hline$s \bar{X}$ & 5.65 & 0.13 & 0.14 & 0.13 & 0.19 & 0.97 & 0.46 & 0.24 & 0.04 & 0.06 & 0.07 & 0.40 \\
\hline Level of significance & NS & 0.01 & 0.01 & 0.01 & NS & 0.01 & 0.01 & NS & 0.01 & 0.01 & 0.01 & 0.01 \\
\hline
\end{tabular}

NS: Not significant; In a column, figures with same letter(s) or without letters do not differ significantly whereas figures with dissimilar letters differ significantly as per DMRT. 
Table 3. Effect of interaction of variety and time of split application of $\mathrm{K}$ on yield and yield contributing characters of $\mathrm{T}$. aman rice

\begin{tabular}{|c|c|c|c|c|c|c|c|c|c|c|c|c|}
\hline $\begin{array}{c}\text { Interaction } \\
\mathrm{V} \times \mathrm{K}\end{array}$ & $\begin{array}{l}\text { Plant } \\
\text { height } \\
(\mathrm{cm})\end{array}$ & $\begin{array}{l}\text { Total } \\
\text { tiller hill }^{-1}\end{array}$ & $\begin{array}{l}\text { Effective } \\
\text { tillers hill }^{-1} \\
\text { (No.) }\end{array}$ & $\begin{array}{l}\text { Non-effective } \\
\text { tillers hill }^{-1} \\
\text { (No.) }\end{array}$ & $\begin{array}{l}\text { Length of } \\
\text { panicle } \\
(\mathrm{cm})\end{array}$ & $\begin{array}{l}\text { Grains/ } \\
\text { panicle }^{-1} \\
\text { (No.) }\end{array}$ & $\begin{array}{l}\text { Unfilled } \\
\text { spikeletspa } \\
\text { nicl }^{-1} \text { (No.) }\end{array}$ & $\begin{array}{l}1000- \\
\text { grain wt(g) }\end{array}$ & $\begin{array}{l}\text { Grain yield } \\
\left(\mathrm{t} \mathrm{ha}^{-1}\right)\end{array}$ & $\begin{array}{l}\text { Straw yield } \\
\left(\mathrm{t} \mathrm{ha}^{-1}\right)\end{array}$ & $\begin{array}{l}\text { Biological } \\
\text { yield } \\
\left(\mathrm{t} \mathrm{ha}^{-1}\right)\end{array}$ & $\begin{array}{l}\text { Harvest } \\
\text { index (\%) }\end{array}$ \\
\hline V1K1 & 83.98 & $8.30 f$ & $5.66 \mathrm{~g}$ & $2.64 \mathrm{cde}$ & 24.44 & $80.84 \mathrm{k}$ & $29.16 a$ & 24.82 & $2.11 \mathrm{~h}$ & $3.19 \mathrm{~g}$ & $5.30 \mathrm{~h}$ & 39.84 \\
\hline V1K2 & 84.23 & $12.27 d$ & $7.52 \mathrm{e}$ & $4.75 a$ & 24.24 & $116.19 \mathrm{i}$ & 27.35ab & 24.63 & $2.61 \mathrm{~g}$ & $3.81 f$ & $6.42 \mathrm{~g}$ & 40.62 \\
\hline V1K3 & 84.97 & $13.81 \mathrm{c}$ & $10.79 b$ & $3.02 \mathrm{bcd}$ & 23.60 & $122.28 \mathrm{~h}$ & $20.89 c$ & 25.31 & $3.27 \mathrm{e}$ & & $7.33 f$ & \\
\hline V1K4 & 82.55 & $12.00 \mathrm{~d}$ & $7.25 \mathrm{e}$ & $4.75 a$ & 23.20 & 110.93j & $25.77 b$ & 24.76 & $3.02 f$ & $4.29 \mathrm{de}$ & $7.31 f$ & 41.29 \\
\hline V2K1 & 115.80 & $10.73 e$ & 7.10ef & $3.63 b$ & 23.08 & $123.14 \mathrm{~h}$ & $18.50 \mathrm{~cd}$ & 24.50 & $3.42 e$ & $4.49 d$ & $7.91 \mathrm{e}$ & 43.28 \\
\hline V2K2 & 116.52 & $13.58 \mathrm{c}$ & $8.40 d$ & $5.18 a$ & 23.86 & $145.92 \mathrm{~g}$ & $15.05 \mathrm{e}$ & 24.80 & $4.12 d$ & $5.46 \mathrm{c}$ & $9.58 c$ & 43.04 \\
\hline V2K3 & 116.51 & $13.12 c$ & $9.54 \mathrm{c}$ & $3.59 b$ & 24.03 & $157.30 d$ & $13.13 e$ & 24.87 & $5.02 a$ & 6.09ab & $11.11 \mathrm{a}$ & 45.18 \\
\hline V2K4 & 78.59 & $12.12 d$ & $8.89 \mathrm{~cd}$ & $3.23 b c$ & 24.20 & $151.93 f$ & $19.10 \mathrm{~cd}$ & 25.54 & $4.37 \mathrm{c}$ & $5.48 \mathrm{c}$ & $9.85 \mathrm{c}$ & 44.35 \\
\hline V3K1 & 128.75 & $8.75 f$ & $6.52 f$ & $2.23 \mathrm{e}$ & 25.73 & $161.35 \mathrm{c}$ & $17.67 d$ & 24.55 & $3.41 \mathrm{e}$ & $5.24 \mathrm{c}$ & $8.65 d$ & 39.41 \\
\hline V3K2 & 125.00 & $13.26 c$ & $11.03 b$ & $2.23 \mathrm{e}$ & 25.51 & $168.50 \mathrm{~b}$ & $14.85 \mathrm{e}$ & 24.42 & $4.62 b$ & $5.97 \mathrm{~b}$ & $10.59 \mathrm{~b}$ & 43.66 \\
\hline V3K3 & 125.61 & $14.68 b$ & $13.21 \mathrm{a}$ & $1.47 f$ & 25.36 & 178.36a & $12.48 \mathrm{e}$ & 24.69 & $5.16 a$ & $6.29 a$ & $11.45 a$ & 45.10 \\
\hline V3K4 & 128.12 & $16.05 a$ & $13.72 \mathrm{a}$ & 2.33de & 25.07 & $154.87 \mathrm{e}$ & $14.72 \mathrm{e}$ & 25.16 & $5.05 a$ & $6.11 \mathrm{ab}$ & $11.15 a$ & 45.26 \\
\hline$s \bar{X}$ & 9.79 & 0.23 & 0.24 & 0.23 & 0.33 & 1.68 & 0.79 & 0.42 & 0.07 & 0.10 & 0.11 & 0.70 \\
\hline CV (\%) & 4.41 & 6.14 & 5.14 & 22.84 & 4.14 & 5.65 & 3.57 & 10.01 & 5.77 & 7.47 & 5.67 & 4.53 \\
\hline $\begin{array}{l}\text { Significanc } \\
\text { e }\end{array}$ & NS & 0.05 & 0.01 & 0.01 & NS & 0.05 & 0.01 & NS & 0.01 & 0.01 & 0.05 & 0.01 \\
\hline
\end{tabular}

NS: Not Significant; In a column figurers with same letter(s) or without letter do not differ significantly whereas figures with dissimilar letters differ significantly as per DMRT.

V1K1=BRRI dhan 39xno K application, V2K3=BRRI dhan 40×two split application of K, V1K2=BRRI dhan $39 \times$ one split application of K, V2K4=BRRI dhan 40xfour split

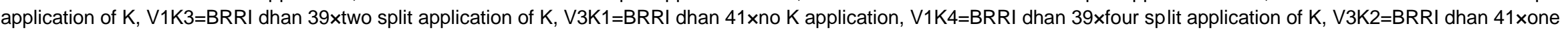
split application of K, V2K1=BRRI dhan $40 \times$ no K application, V3K3=BRRI dhan $41 \times$ two split application of K, V2K2=BRRI dhan $40 \times$ one split application of K, V3K4=BRRI dhan $41 \times$ four split application of $\mathrm{K}$. 


\section{Interaction Effect of Variety and K split application}

\section{Total Tiller Hill-1}

The variety BRRI dhan41 with four splits application of $\mathrm{K}$ gives the highest number of total tillers hill ${ }^{-1}$. The lowest number tillers hill-1 was found in variety BRRI dhan41 with basal application of $\mathrm{K}$ which is statistically similar to variety BRRI dhan39 with basal application of $\mathrm{K}$.

\section{Number of Effective Tillers Hill ${ }^{-1}$}

Table 3 shows that the highest number of effective tillers hill-1 was counted in the combination of variety BRRI dhan41 with two splits application of $\mathrm{K}$ which is statistically similar to the combination of variety BRRI dhan41 with four splits application of $\mathrm{K}$. Lowest number of tillers hill-1 was found in BRRI dhan39 with basal application of $\mathrm{K}$.

\section{Number of non-effective tillers hill-1}

The trend of interaction effect between variety and split application of potassium was found to have adverse effect in BRRI dhan40on the production of non-effective tillers hill ${ }^{-1}$ with one split application which is statistically similar to BRRI dhan39 with four split application of K. Less number non-effective tillers hill ${ }^{-1}$ was found BRRI dhan41 with two split application of $\mathrm{K}$ which might have caused greater production.

\section{Grain Panicle ${ }^{-1}$}

The combination of variety BRRI dhan41 with two splits application of $\mathrm{K}$ produced higher number of grains panicle ${ }^{-1}$ and variety BRRI dhan39 with basal application of $\mathrm{K}$ shows the lower number of grain panicle ${ }^{-1}$.

\section{Unfilled spikelets panicle ${ }^{-1}$}

The maximum number of unfilled spikelets panicle ${ }^{-1}$ was observed in BRRI dhan39 with no $\mathrm{K}$ application which is statistically similar to BRRI dhan39 with one split application. The lowest number of unfilled spikelets panicle ${ }^{-1}$ was found in BRRI dhan40 with one split application of $\mathrm{K}$ which is statistically similar to BRRI dhan 40 with two split, BRRI dhan 41 with one split, two split and four split application of K.

\section{Grain yield}

The highest number of grain yield was found in the interaction between variety BRRI dhan41 with two splits application of $\mathrm{K}$ which is statistically similar to the interaction between variety BRRI dhan41 with four splits application of $\mathrm{K}$ and variety BRRI dhan 40 with two splits application of $\mathrm{K}$. Lowest number of grain yield found in BRRI dhan39 with basal dose.

\section{Straw yield}

The highest number of straw yield was found in the interaction between variety BRRI dhan41 with two splits application of $\mathrm{K}$ which is statistically similar to the interaction between variety BRRI dhan41 with four splits application of $\mathrm{K}$ and variety BRRI dhan40 with two splits application of $\mathrm{K}$. In every variety, straw yield increased gradually in one split then two split application of potassium, In case of four split application of potassium, except BRRI dhan39 other two varieties showed less number of straw yield.

\section{Biological yield}

The maximum Biological yield was obtained from BRRI dhan40 with two split application of potassium which is identical with BRRI dhan41 with two split application of potassium and four split of Potassium. There is a great difference in biological yield of BRRI dhan40 and BRRI dhan41 in compared to BRRI dhan39 in case of two split application of potassium.

\section{CONCLUSION}

Based on the findings of the present study, it may be concluded that for obtaining higher yield BRRI dhan 41 can be grown following application of potassium at the rate of $80 \mathrm{~kg} \mathrm{ha}^{-1}$ in two equal split at 15 and 30 days after transplanting. 


\section{REFERENCES}

1. Rajesh K, Thakral SK, Satish K and Mehta AK, 2008. Effect of split application of Potassium on nutrient content and yield of rice. Environment and Ecology, 26: 474-476.

2. Rajesh K, Thakral SK and Satish K, 2007. Effect of split application of potassium on nutrient uptake and quality of rice. Hisar, India: Agricultural Research Information Centre.

3. Singh GR, Dixit RS and Dwivedi AP, 2006. Effect of nitrogen, phosphorus and potassium levels on growth, yield and quality of hybrid rice (Oryza sativa L.) Agron. N. D University Agriculture Technology, India. 43(1): 64-66.

4. Arivazhagan $\mathrm{K}$ and Ravichandran $\mathrm{M}, 2005$. Interaction effect of nitrogen and potassium on yield and yield attributes in rice cv. IR 20 Advances-in-Plant-Sciences, 18(1): 425-427.

5. Yadav SL, Ramteke JR, Gedam VB and Powar MS, 2004. Effect of time of application of potassium on the yield and nutrient uptake of rice hybrids. Journal of Maharashtra Agricultural Universities, 29(2): $242-243$

6. Meena SL, Singh S and Shivay YS, 2003. Response of rice ( Oryza sativa) to $\mathrm{N}$ and $\mathrm{K}$ application in sandy loam soils. Indian Journal Agricultural Science, 73(1): 08-11.

7. Anac D, Kilic OG, Eryuce $\mathrm{N}$ and Okur B, 2003. Effect of potassium amount and time of application on rice yields under water deficit condition. Potassium and water management in West Asia and North Africa Proceedings of the Regional Workshop of the International Potash Institute, Amman, Jordan, 5-6 November 2001, 67-75.

8. Yadav SL, Ramteke JR, Gedam VB and Powar MS, 2004. Effect of time of application of potassium on the yield and nutrient uptake of rice hybrids. Journal of Maharashtra Agricultural Universities, 29(2): 242-243.

9. Kanti $P$ and Chauhan RPS, 2000. Rice response to rate and time of application of potassium in an upland. Journal of Potassium Research, 16: 32-34.

10. Thippeswamy HM, Shivakumar BG and Balloli SS, 2000. Potassium transformation studies in lowland rice (Oryza sativa L.) as influenced by levels and time of $\mathrm{K}$ application. Journal of Potassium Research, 16: 7-11.

11. Pal S, Ghosh SK, Mukhopadhyay AK, 2000. Split application of potassium on rice (Oryzasativa) in coastal zone of West Bengal. Indian Journal of Agronomy, 45(3): 575-579

12. Surekha K, Reddy MN and Vijaykumar CHM, 1998. Response of rice hybrids of $\mathrm{N}$ sources and time of application of N and K. International Rice Research Notes, 23(2): 43.

13. Singh $M$ and Singh RK, 1998. Agronomic and economic evaluation of response of rice to potassium. Indian experience. In Potassium in Soils and Crops, Potash. Inst. New Delhi, India, pp. 265-267.

14. Devasenapathy P, 1997. Split application of potassium in rice. Madras Agricultural Journal, $84(5)$ : 265-266.

15. Fallah VM, 1997. Influence of date of K application on rice yield at Mazandaran, Iran. Soil and Water Journal, 10(1): 45-54.

16. Muthumanickam D, Ravichandran M and Sriramachandra SMV, 1996. Effects of time of split application of $\mathrm{K}$ on soil $\mathrm{N}$ forms and lowland rice yield. International Rice Research Notes, 21: 6768.

17. Kalita U, Ojha NJ and Talukdar MC, 1995. Effect of levels and time of potassium application on yield and yield attributes of upland rice. Journal of Potassium Research, 11(2): 203-206.

18. Das NR, 1990. Effect of level and time of application of potassium on the growth and yield of kharif rice Oryaza sativa. Environment and Ecology, 8: 290-292.

19. Velayutham A and velyautham K, 1991. Spilt application of potassium to rice (Oryzastaiva) in saline soils. Indian Journal Agronomy, 36 (4): 585-586. 